\title{
Examination of Legibility and Writing Speeds of Primary School Students with Respect to Writing Disposition and Writing Style
}

\author{
Aysel Demiroğlu Memiş \\ Department of Elementary Education, Faculty of Education, Bulent Ecevit University, Turkey
}

Copyright $\bigcirc 2018$ by authors, all rights reserved. Authors agree that this article remains permanently open access under the terms of the Creative Commons Attribution License 4.0 International License

\begin{abstract}
Relational screening from descriptive screening models was used in this study in which legibility and speeds of writings of primary school students with respect to writing disposition and different writing styles were examined. A sample of 325 children in the 4 th and 5 th grades attending schools in the Kdz. Eregli participated into the study. According to the results of the study, writing dispositions of the girl students in both grades were higher than those of the boy students, and there was a significant different there between. While the writing dispositions of the fifth grade students were higher, it did not differentiate with the fourth grade students. There was a high-level, positive and significant relationship between cursive italic writing and manuscript writing legibility. There was a positive, medium-level and significant relationship between cursive italic writing legibility and writing speed with manuscript letters. There was a medium-level, positive and significant relationship between manuscript writing speed and cursive italic writing speed. In both writing style, as legibility increased, writing disposition points also increased; in all legibility dimensions, a significant difference was determined between the students in terms of writing disposition.
\end{abstract}

Keywords Primary Education, Writing Disposition, Writing Style, Legibility, Writing Speeds

\section{Introduction}

Turkish Course Teaching Program (38) consists of three learning areas as "listening", "talking", "reading" and "writing". Within the program, acquisitions relating to grammar, grammatical rules, understanding what is read, and written expression skills are structured with an increasing density and depth considering age, level, language and mental developments of the students. As of
2005 in Turkey, teaching education was initiated with cursive italic writing as of the first grade and writing studies in all class grades were performed with cursive writing letters, and applications were carried out in this manner. After 12 years of this application, it was announced by the Ministry of National Education that manuscript writing would be adopted as of 2016-2017 educational years. The process being initiated with scientific studies was concluded with public pressure. With the final decision, it was stated that the preference would be left on class teacher. It is known that some of the teachers support this change. Duran [15] stated as a result of his study that $16 \%$ of teachers did not regard cursive italic writing meaningful, and they wanted to return writing education with manuscript letters.

Writing skill is a process that needs to be developed from preschool period, not 1 st grade. Preparation processes for writing as a psychomotor skill are experienced during preschool period; however, it should be considered that preschool education is not within compulsory education scope in our country. Although preschool education is not compulsory, it is a demanded education procedure. Due to reasons such as socialization and working mothers, children in city centers attend preschool education for a few years. With changes in regulation of primary school institutions, school starting age has been decreased down to 60 months with parent permission. There are differences in writing processes due to reasons such as having preschool education and age factor. It is known that academic achievement is related to the success of handwriting performance $[10,18,32,16]$. In addition, as Graham, Harris and Fink [23] stated that teachers were liable to grade legible writing higher, it may be said to affect academic success as well.

There are scale development studies for determining writing dispositions of the students and studies examining statuses of students in different age groups and with different variables in Turkey and abroad $[35,25,27,28$, 
$31,40,37,5,6,7,39,4,9,3,13,26,30]$.

The most important reasons for insufficiency of student writings in terms of legibility are stated as "insufficient and irregular education". The fact that writings written on class board by the teacher are legible has a great importance for legible writing skill acquisition of the students. For example, the fact that some teachers do not write onto the board in due form in front of the students constitutes a typical example of irregular education [1]. Yıldız, Yildırım and Ateş [41] determined, as the result of the study examining the status of being a model for students by class teachers in terms of legibility of writings written on the class board, that most teachers used cursive italic writing, that there were also a number of teachers using manuscript writing and that some teachers used both writing styles. It was seen that almost half of the teachers using cursive italic writing had insufficient inclination in their writings, and medium-level sufficiency in the whole writing in terms of spacing, dimension, shape and line tracking. Moreover, it was understood that writings written onto the black board was more sufficient than those written onto the white board in terms of legibility. According to the study results of Coşkun and Coşkun [12], the class teachers have medium-level cursive italic writing success.

It was revealed in the studies conducted $[14,8,42]$ that majority of the students writing of which speed and legibility were known to be profoundly important $[19,20]$ were not sufficient in terms of legibility. It was stated that writing skill was developed with age and education taken from school (Graham and Weintraub) and legibility levels were shaped in the fourth grade (Mojet) (cited by: [42]). Memiş and Gülsoy [33] indicated that legibility of the writings of the students reduced as grade increased. Erdoğan [17] assessed the texts written with cursive italic writing at the beginning and end of the first semester and at the end of the second semester of the first grade students using "Cursive Italic Writing Assessment Form", and it was concluded that cursive italic writings of the students did not exhibit development in terms of legibility, and that it exhibited development in terms of writing speed. Arslan and Ilgin [2] stated as a result of their study that the students liked writing and generally they regarded their own writing as "good". The students wanted to write with cursive italic writing, they preferred cursive italic writing because it was nicely and easily written, not because it was compulsory. In the studies conducted, it was determined that there was no relationship between attitudes of the students relating to cursive italic writing and writing speed, while there was a positive, significant relationship between cursive italic writing skill and writing speed [29].
In recent years, students should use which writing style a hotly debated issue in Turkey. For that reason, the cursive italic handwriting and basic vertical writing, which are discussed the two writing styles are emphasized in the research. In this study, legibility statuses and writing speeds of the primary school students with respect to writing disposition and different writing styles (cursive italic writing- manuscript writing) were examined. This study conducted in our country discussing which writing style should be used is considered to contribute literature and application.

\section{Materials and Methods}

\subsection{Participants}

A sample of 325 children in 4th-5th grades attending schools in the Kdz. Ereğli participated into the study (163 boys and 162 girls). The students in 4th-5th grades attended four different public schools and eleven different classrooms.

\subsection{Instruments}

\subsubsection{Writing Disposition Scale}

Writing disposition measurement of the students was conducted with the writing disposition scale which was developed by Piazza and Siebert [35] and adapted to Turkish by İşeri and Ünal [27]. The final version of the scale consisted of 11 items. The lowest point to be taken was 11 , and the highest was 55 . Higher points taken from the scale indicated that writing dispositions of the students were positive, while lower points indicated that writing dispositions were negative. The scale was found to be valid and reliable for its own sample.

\subsubsection{Multi-dimensional Legibility Scale}

The scale developed by Yıldız and Ateş [42] was used for the assessment of the legibility of the student writings. In this scale prepared in accordance with the approach of analytical assessment, the legibility was assessed in terms of five factors as inclination, spacing, dimension, shape and line tracking. Each factor was graded as completely sufficient (3), partially sufficient (2) and not sufficient (1). Considering that the lowest point to be taken from this scale was 5 , and the highest was 15 , writings of the students with a total point between 5-8.3 were assessed as, a total point between $8.4-11.7$ as medium-level legible and a total point between $11.8-15$ as legible. 
Example 1: Illegible cursive italic handwriting and manuscript writing

Student 1:

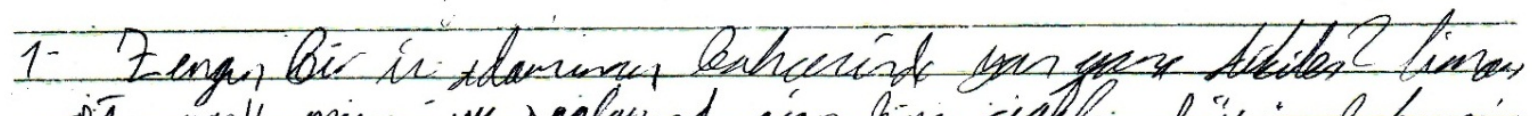

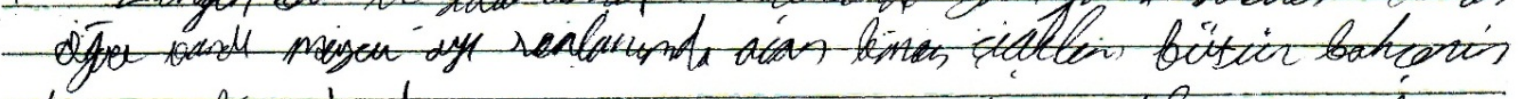

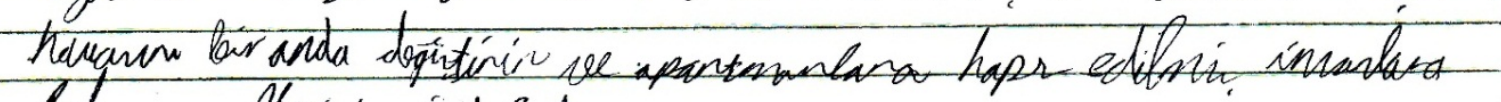

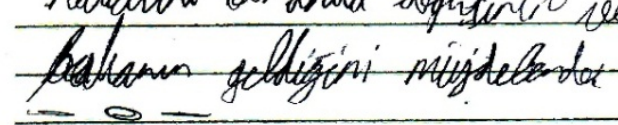

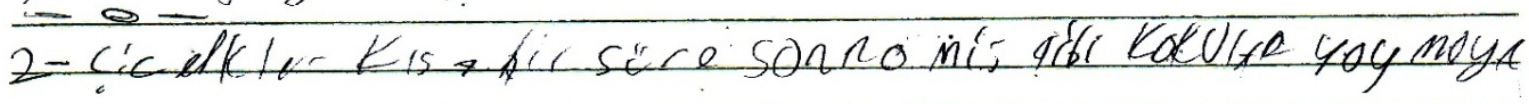

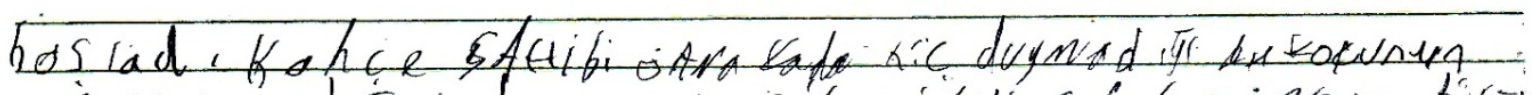

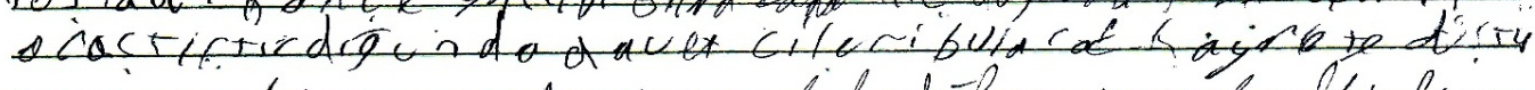

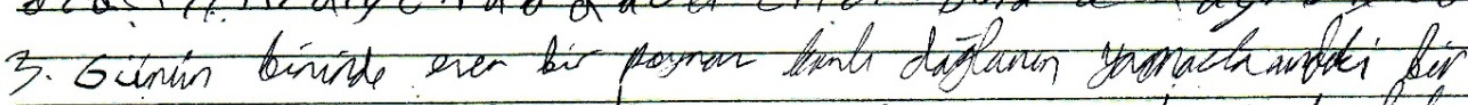

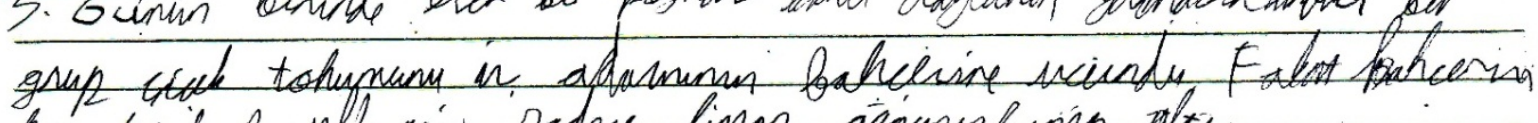

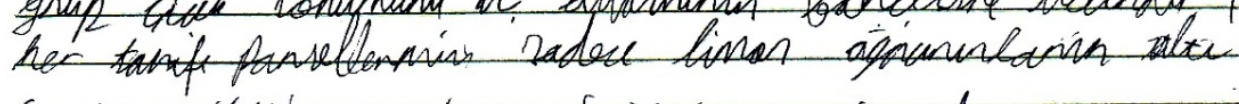

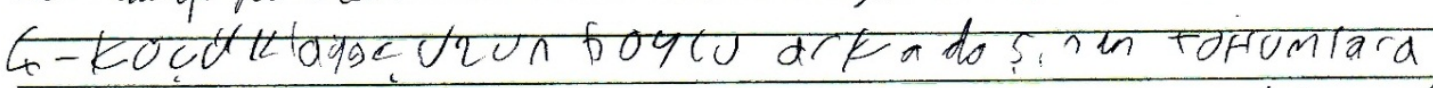
Verdigi cecrobibeḡen misti toftumlaci- selpil met

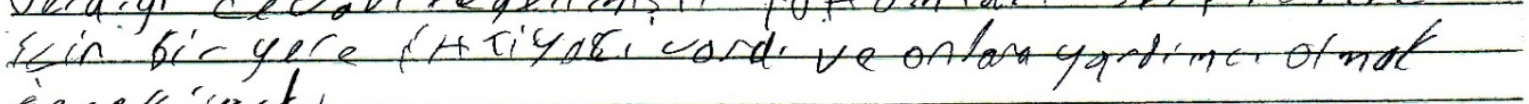
besteifjoto

Student 2:

\begin{tabular}{|c|}
\hline 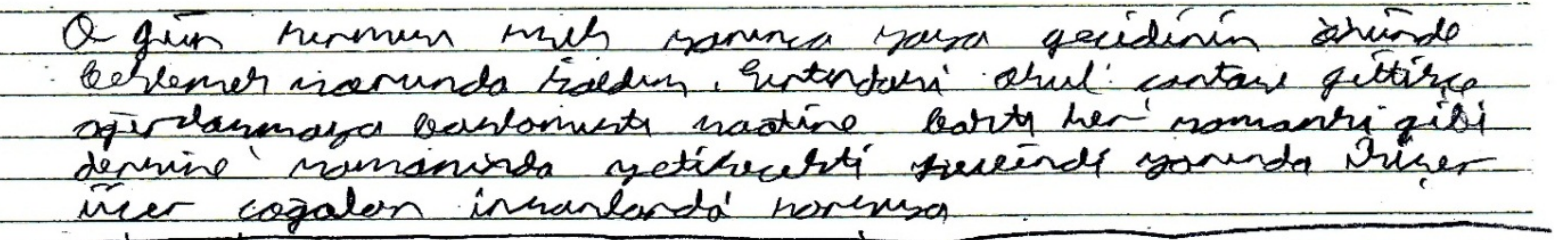 \\
\hline 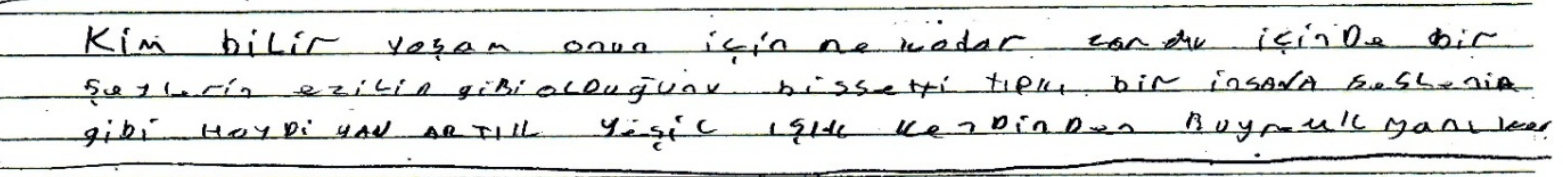 \\
\hline 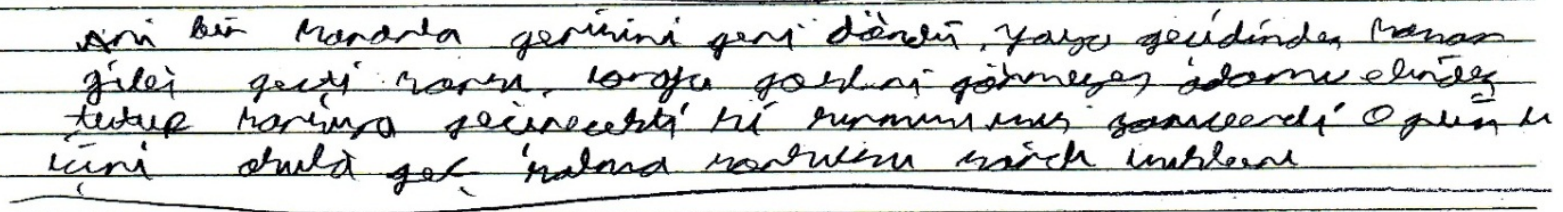 \\
\hline 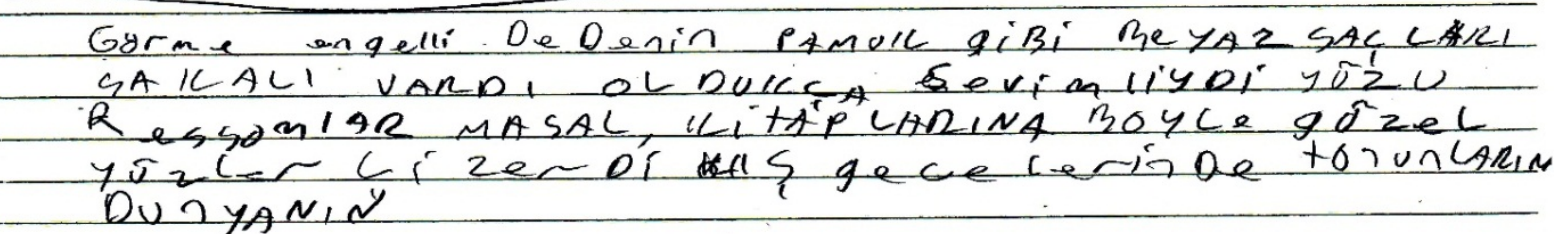 \\
\hline
\end{tabular}


Example 2: Legible cursive italic handwriting and manuscript writing

Student 1:
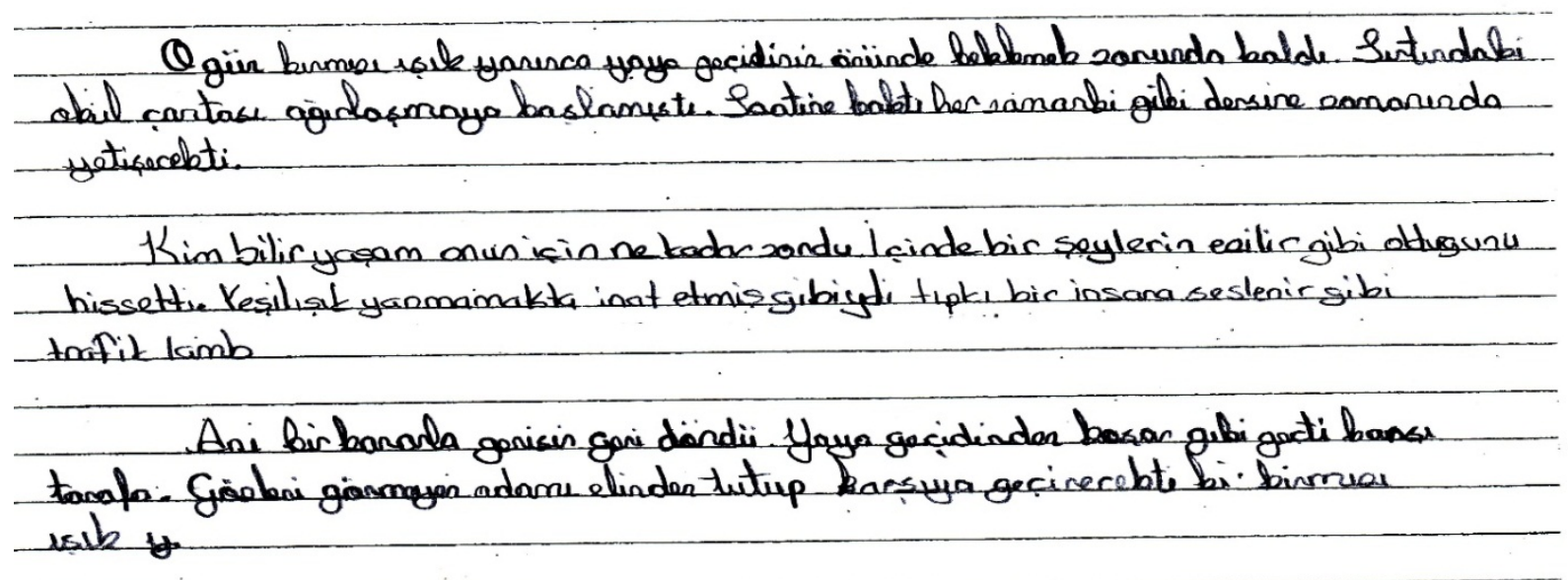

Görme engell. pamul gibi bembeyaa sack tarl, sakal, vardi. Olduked sevimliydi yuivi. Ressamlar, masal Litaptar ina bäyle gäzel yǘler cinerlerdi Kusecelesinde torustanina dinyanen en

Student 2:

Lengin bir is adamin bakcesinde yan yana dikilen ikí limon ájace cande. Mayjes aye sonlarinda acan limon ciceblen bietion bahcenin havasin bir andá degéstinir ve apantmanlara haps edilmís 1

Cicekler kisa bir sure sonea mis gibi kokular yaymaya basladi Bahce sahibio ana kadar hic duymadigi bo kokunun nenciden geldig̈ís arastindiginda arastindiginda davet siz misafíderi bularak ha

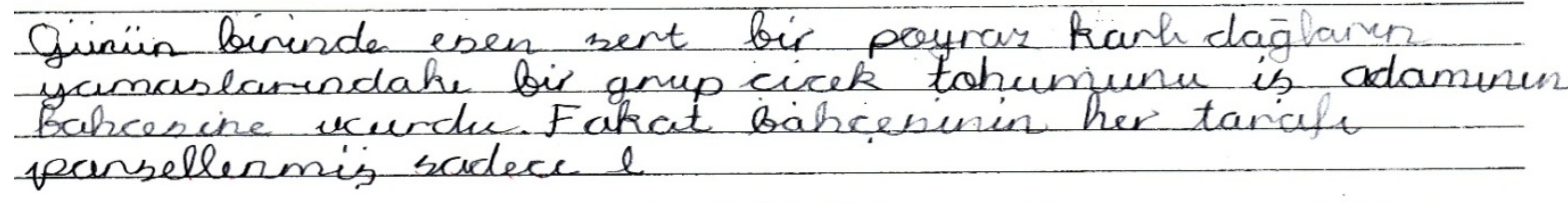

kucuk agac uzun boylu arkadasinin tohumlara vendigi cevabi segenmemisti. Tohumlanin serpilmek icin bir yeer ihtigaci yand, re antara bu kanuda yardema olmak gerekigonde. hu yusden

\subsubsection{Writing Speed}

Writing speeds of the students were determined with dictation of sentences read by the researcher. The students were asked to write for 2 minutes with pencil and the average writing speed was determined according to the number of letters written in 1 minute. According to Güneş [24] the determination of the number of letters written per minute by the students is the most proper measurement.
Graham and oth. [21] present writing speed averages in accordance with gender and grade in Table 1 below.

Table 1. Letter-Based 1-Minute Average Writing Speeds of The Children In Primary School 1st-5th Grades With Respect to Their Gender

\begin{tabular}{|c|c|c|c|c|c|}
\hline Grades & 1 & 2 & 3 & 4 & 5 \\
\hline Girl & 20,51 & 36,77 & 49,80 & 65,78 & 74,57 \\
\hline Boy & 17,44 & 31,55 & 44,80 & 60,58 & 70,91 \\
\hline
\end{tabular}




\subsection{Procedures}

T-test was used for determination of writing dispositions of the students with respect to gender and grades; frequency, percentage and chi-square for measurement of legibility and writing speeds with respect to gender and grade; one-way ANOVA for correlation between legibility and speed and legibility and writing disposition scores; frequency and percentage procedures for preferred writing style and writing speed.

\section{Results}

\subsection{Writing Disposition With Respect to Gender and Grades}

Table 2. Writing Disposition Scores With Respect to Gender and Grades

\begin{tabular}{|c|c|c|c|c|c|c|c|}
\hline \multicolumn{2}{|c|}{$\begin{array}{c}\text { Gender and } \\
\text { Grade }\end{array}$} & $\mathbf{N}$ & M & $\mathbf{S}$ & df & $\mathbf{t}$ & $\mathbf{P}$ \\
\hline \multirow{2}{*}{ Fourth } & Girl & 71 & 86,24 & 10,78 & \multirow{2}{*}{145} & \multirow{2}{*}{4,780} & \multirow{2}{*}{, 000} \\
\hline & Boy & 76 & 76,13 & 14,44 & & & \\
\hline \multirow{2}{*}{ Fifth } & Girl & 92 & 85,53 & 11,02 & \multirow{2}{*}{176} & \multirow{2}{*}{2,308} & \multirow{2}{*}{,022 } \\
\hline & Boy & 86 & 81,14 & 14,26 & & & \\
\hline \multirow{2}{*}{ Total } & Fourth & 147 & 81,01 & 13,73 & \multirow{2}{*}{323} & \multirow{2}{*}{$-1,622$} & \multirow{2}{*}{, 106 } \\
\hline & Fifth & 178 & 83,41 & 12,84 & & & \\
\hline
\end{tabular}

While writing dispositions of the fifth grade students are higher, it does not differentiate in the fourth grade students $(p>, 05)$. In both grades, writing dispositions of the girl students are higher than those of boy students, and there is a significant difference there between $(\mathrm{p}<, 05)$. Writing disposition points of the boy students exhibited increase along with grade.

\subsection{Legibility and Writing Speed With Respect to Gender and Grade}

Legibility of the writings of the students shows similarity in both writing styles. There is a high-level, positive and significant relationship between cursive italic writing and manuscript writing legibility $(\mathrm{r}=, 828 \mathrm{p}<, 01)$. Majority of the students with legible cursive italic writing have legible manuscript writing as well, despite not having been taught before. It is observed that the students with illegible cursive italic writing mostly have illegible manuscript writing as well. It is seen that the students reflect their own writing characters similarly in both writing styles. On examination of writing speeds of the students, there is a medium-level, positive relationship between cursive italic writing and manuscript writing speed $(\mathrm{r}=, 366 \mathrm{p}<, 01)$.

The ratio of the students is $13,2 \%$ with illegible, $52 \%$ with medium-level legible, and $34,8 \%$ with legible cursive italic writing. In manuscript writing, writings of the students are illegible with a ratio of $17,8 \%$, medium-level legible with a ratio of $47,2 \%$, and legible with a ratio of $35,1 \%$.

On assessment between the girl and the boy students, the ratio of illegible writing is $5,5 \%$ in the girl students, while $21 \%$ in the boy students. $43,6 \%$ of the girl students and $60,5 \%$ of the boy students write medium-level legibly, while $50,9 \%$ of the girl students and only $18,5 \%$ of the boy students write legibly. In manuscript writing, $6,1 \%$ of the girl students and $29,6 \%$ of the boy students write illegibly. $41,1 \%$ of the girl students and $53,2 \%$ of the boy students write medium-level legibly, while $52,8 \%$ of the girl students and only $17,3 \%$ of the boy students write legibly. Legibility of the writings of the girl and the boy students differentiates for each writing style (Cursive italic writing $\chi^{2}(2)=43,704 \mathrm{p}<, 05$, manuscript writing $\left.\chi^{2}(2)=56,762 \mathrm{p}<, 05\right)$. The ratio of illegible writing of fourth grade girl students is $1,4 \%$, ratio of medium-level legibility is $42,3 \%$ and ratio of legible writing is $57,3 \%$. It is seen that, in the fifth grade, the ratio of illegible writing of the girl students is reduced down to $8,7 \%$, and medium-level legibility is increased up to $44,6 \%$ and ratio of legible writing is reduced down to $48,7 \%$. Legibility of the boy students is lower than that of the girl students. Ratio of illegible writing in cursive italic writing is $14,5 \%$, medium-level legibility ratio is $61,8 \%$ and legible writing ratio is $25,7 \%$. In the fifth grade, the writings are illegible with a ratio of $26,7 \%$, medium-level legible with a ratio of $59,3 \%$ and legible with a ratio of $15 \%$. In manuscript writing for fifth grade, ratio of illegible writing is $7 \%$ in the girl students and $26,3 \%$ in the boy students. Medium-level legibility ratio is 40,8 in the girl students and $55,3 \%$ in the boy students. The ratio of legible writing is $52,2 \%$ in the girl students and $19,4 \%$ in the boy students. In the fifth grade, the ratio of illegible writing is $5,4 \%$ in the girl students and $32,6 \%$ in the boy students; ratio of medium-level legibility is $41,3 \%$ in the girls and $51,2 \%$ in the boys; the ratio of legible writing is $54,3 \%$ in the girl students and $17,2 \%$ in the boy students. In the fourth grade level, there is a differentiation with respect to gender in both cursive italic writings $\left(\chi^{2}(2)=20,285\right.$ $\mathrm{p}<, 05)$ and manuscripts $\left(\chi^{2}(2)=21,608 \mathrm{p}<, 05\right)$. Legibility of the writings of the fifth grade students differentiates with respect to gender in both cursive italic writings $\left(\chi^{2}(2)\right.$ $=25,645 \mathrm{p}<, 05)$ and manuscripts $\left(\chi^{2}(2)=35,752 \mathrm{p}<, 05\right)$.

Cursive italic writings of the fourth grade students are more legible than those of the fifth grade students. The difference observed in statutes of the fourth and the fifth grade legibility of the students is significant $\left(\chi^{2}(2)=6,91\right.$ $\mathrm{p}<, 05)$. Moreover, there is no significant difference found in manuscript writing with respect to grades $\left(\chi^{2}(2)=, 202\right.$ $\mathrm{p}>, 05)$. Cursive italic writings of $8,2 \%$ of the fourth grade students were illegible, while this ratio was $17 \%$ in manuscripts for the same students. In fourth grade level, cursive italic writings of $17,4 \%$ of the students were illegible, and this ratio was close to the ratio of illegible writing with manuscript $(18,5 \%) .52,4 \%$ of the fourth 
grade students wrote cursive italic writing medium-level legibly, while $48,3 \%$ wrote manuscript writing medium-level legibly. In this class, $40,4 \%$ of the students wrote cursive italic writing and $35,7 \%$ wrote manuscripts legibly. $51,7 \%$ of the fifth grade students wrote cursive italic writing medium-level legibly, while $46,1 \%$ wrote manuscript writing medium-level legibly. In this class, $32,9 \%$ of the students wrote cursive italic writing and $36,4 \%$ wrote manuscript writing legibly.

It was determined that cursive italic writing was written more rapidly than manuscript writing. This situation was more obvious for male students. Cursive italic writing letter averages per minute for the girl students was 75,92, and those of the boy students were 78,58. In manuscript writing, the girl students wrote 72,40 letters per minute, and the boy students reduced the average down to 56,52 .

Cursive italic writings of the fifth grade students $(81,16)$ were significantly faster than those of the fourth grades $(72,51)$. In both grades, the boy students wrote cursive italic writing more rapidly than the girl students. The situation was different for writing with manuscripts. Although number of letters written per minute showed increase in the fifth grade students compared to the fourth grade students, it was seen that the girl students wrote more rapidly than the boy students in both grades. Writing speeds of the boy students with manuscripts were below the cursive italic writing averages.

As cursive italic writing speeds of the students increased, legibility of their writings decreased. This situation was similar in both grades. As writing speeds of the girl students increased, the legibility decreased. The situation was different for the boy students. Although total points showed similarity with these results, it was concluded that the boy students in the fifth grade wrote rapidly and legibly. Contrary to the previous result of the students, as cursive italic writing legibility increased, manuscript writing speed increased as well. This showed similarity for both genders. There was a similar table for the boy students in both grades as well. The group from the boy students who wrote manuscript writing most rapidly was the one with students with legible cursive italic writing.

There was no differentiation in cursive italic writing speeds of the students with respect to manuscript writing legibility statuses, the writing speeds were close to each other in all reading levels. There was also no difference seen for age and gender variables. An increase was seen in manuscript writing speeds of the students as manuscript writing legibility increased. The situation was the same for both the girls and the boys in all grades. Cursive italic writing speeds of the students were higher than manuscript writing in all legibility levels.

Table 3. Cursive Italic Writing Legibility and Writing Speed with respect to Gender and Grade

\begin{tabular}{|c|c|c|c|c|c|c|c|c|c|c|c|}
\hline & & & \multicolumn{3}{|c|}{ Girl } & \multicolumn{3}{|c|}{ Boy } & \multicolumn{3}{|c|}{ Total } \\
\hline & \multicolumn{2}{|c|}{ Cursive Italic Writing } & $\mathrm{N}$ & $\mathrm{M}$ & $\mathrm{S}$ & $\mathrm{N}$ & M & $\mathrm{S}$ & $\mathrm{N}(\%)$ & $\mathrm{M}$ & $\mathrm{S}$ \\
\hline \multirow{12}{*}{$\begin{array}{l}\text { Cursive } \\
\text { Italic } \\
\text { Writing } \\
\text { Speed }\end{array}$} & \multirow{4}{*}{ 4th grade } & 1.Illegible & $1(1,4)$ & 74,00 & - & $11(14,5)$ & 78,82 & 24,39 & $12(8,2)$ & 78,42 & 23,29 \\
\hline & & 2.Medium-level Legible & $30(42,3)$ & 70,32 & 18,51 & $47(61,8)$ & 74,01 & 15,97 & $77(52,4)$ & 72,57 & 16,98 \\
\hline & & 3.Legible & $40(57,3)$ & 69,95 & 17,69 & $18(25,7)$ & 74,03 & 16,58 & $58(40,4)$ & 71,22 & 17,31 \\
\hline & & Total & $71(100)$ & 70,16 & 17,79 & $76(100)$ & 74,71 & 17,35 & $147(100)$ & 72,51 & 17,65 \\
\hline & \multirow{4}{*}{ 5th grade } & 1.Illegible & $8(8,7)$ & 85,38 & 10,74 & $23(26,7)$ & 84,17 & 18,06 & $31(17,4)$ & 84,48 & 16,32 \\
\hline & & 2.Medium-level Legible & $41(44,6)$ & 84,88 & 18,07 & $51(59,3)$ & 80,00 & 21,04 & $92(51,7)$ & 82,17 & 19,82 \\
\hline & & 3.Legible & $43(48,7)$ & 75,13 & 18,03 & $12(15,0)$ & 86,37 & 13,79 & $55(32,9)$ & 77,58 & 17,71 \\
\hline & & Total & $92(100)$ & 80,36 & 18,08 & $86(100)$ & 82,01 & 19,38 & $178(100)$ & 81,16 & 18,69 \\
\hline & \multirow{4}{*}{ Total } & 1.Illegible & $9(5,5)$ & 84,11 & 10,74 & $34(21,0)$ & 82,44 & 20,10 & $43(13,2)$ & 82,79 & 18,44 \\
\hline & & 2.Medium-level Legible & $71(43,6)$ & 78,73 & 19,52 & $98(60,5)$ & 77,13 & 18,92 & $169(52,0)$ & 77,80 & 19,14 \\
\hline & & 3.Legible & $83(50,9)$ & 72,63 & 17,95 & $30(18,5)$ & 78,97 & 16,47 & $113(34,8)$ & 74,31 & 17,72 \\
\hline & & Total & $163(100)$ & 75,92 & 18,61 & $162(100)$ & 78,58 & 18,76 & $325(100)$ & 77,25 & 18,70 \\
\hline \multirow{12}{*}{$\begin{array}{c}\text { Manuscript } \\
\text { Writing } \\
\text { Speed }\end{array}$} & \multirow{4}{*}{ 4th grade } & 1.Illegible & $1(1,4)$ & 75,50 & - & $11(14,5)$ & 48,14 & 36,67 & $12(8,2)$ & 50,42 & 35,84 \\
\hline & & 2.Medium-level Legible & $30(42,3)$ & 63,70 & 20,08 & $47(61,8)$ & 48,60 & 20,95 & $77(52,4)$ & 54,48 & 21,78 \\
\hline & & 3.Legible & $40(57,3)$ & 71,58 & 18,42 & $18(25,7)$ & 55,14 & 23,40 & $58(40,4)$ & 66,47 & 21,31 \\
\hline & & Total & $71(100)$ & 68,30 & 19,28 & $76(100)$ & 50,08 & 24,09 & $147(100)$ & 58,88 & 23,66 \\
\hline & \multirow{4}{*}{5 th grade } & 1.Illegible & $8(8,7)$ & 62,69 & 26,90 & $23(26,7)$ & 54,89 & 20,25 & $31(17,4)$ & 56,90 & 21,94 \\
\hline & & 2.Medium-level Legible & $41(44,6)$ & 77,15 & 17,96 & $51(59,3)$ & 61,71 & 22,09 & $92(51,7)$ & 68,59 & 21,67 \\
\hline & & 3.Legible & $43(48,7)$ & 76,47 & 14,31 & $12(15,0)$ & 78,33 & 20,07 & $55(32,9)$ & 76,87 & 15,55 \\
\hline & & Total & $92(100)$ & 75,57 & 17,55 & $86(100)$ & 62,20 & 22,28 & $178(100)$ & 69,11 & 21,02 \\
\hline & \multirow{4}{*}{ Total } & 1.Illegible & $9(5,5)$ & 64,11 & 25,53 & $34(21,0)$ & 52,71 & 26,29 & $43(13,2)$ & 55,09 & 26,25 \\
\hline & & 2.Medium-level Legible & $71(43,6)$ & 71,46 & 19,90 & $98(60,5)$ & 55,42 & 22,43 & $169(52,0)$ & 62,16 & 22,77 \\
\hline & & 3.Legible & $83(50,9)$ & 74,11 & 16,50 & $30(18,5)$ & 64,42 & 24,64 & $113(34,8)$ & 71,54 & 19,36 \\
\hline & & Total & $163(100)$ & 72,40 & 18,62 & $162(100)$ & 56,52 & 23,86 & $325(100)$ & 64,48 & 22,80 \\
\hline
\end{tabular}



with Respect to Writing Disposition and Writing Style

Table 4. Manuscript Writing Legibility and Writing speed with respect to Gender and Grade

\begin{tabular}{|c|c|c|c|c|c|c|c|c|c|c|c|}
\hline & & & \multicolumn{3}{|c|}{ Girl } & \multicolumn{3}{|c|}{ Boy } & \multicolumn{3}{|c|}{ Total } \\
\hline & \multicolumn{2}{|c|}{ Manuscript writing } & $\mathrm{N}(\%)$ & M & $\mathrm{S}$ & $\mathrm{N}(\%)$ & M & $\mathrm{S}$ & $\mathrm{N}(\%)$ & M & $\mathrm{S}$ \\
\hline \multirow{12}{*}{$\begin{array}{l}\text { Cursive } \\
\text { Italic } \\
\text { Writing } \\
\text { Speed }\end{array}$} & \multirow{4}{*}{ 4th grade } & 1.Illegible & $5(7,0)$ & 65,50 & 17,73 & $20(26,3)$ & 74,82 & 19,36 & $25(17,0)$ & 72,96 & 19,07 \\
\hline & & 2.Medium-level Legible & $29(40,8)$ & 70,03 & 17,99 & $42(55,3)$ & 74,29 & 16,52 & $71(48,3)$ & 72,55 & 17,14 \\
\hline & & 3.Legible & $37(52,2)$ & 70,89 & 18,04 & $14(19,4)$ & 75,82 & 18,02 & $51(35,7)$ & 72,25 & 17,99 \\
\hline & & Total & $71(100)$ & 70,16 & 17,79 & $76(100)$ & 74,71 & 17,35 & $147(100)$ & 72,51 & 17,65 \\
\hline & \multirow{4}{*}{5 th grade } & 1.Illegible & $5(5,4)$ & 87,30 & 12,12 & $28(32,6)$ & 81,45 & 17,64 & $33(18,5)$ & 82,33 & 16,90 \\
\hline & & 2.Medium-level Legible & $38(41,3)$ & 84,91 & 18,00 & $44(51,2)$ & 82,74 & 20,91 & $82(46,1)$ & 83,74 & 19,53 \\
\hline & & 3.Legible & $49(54,3)$ & 76,13 & 17,83 & $14(17,2)$ & 80,82 & 18,98 & $63(36,4)$ & 77,17 & 18,04 \\
\hline & & Total & $92(100)$ & 80,36 & 18,08 & $86(100)$ & 82,01 & 19,38 & $178(100)$ & 81,16 & 18,69 \\
\hline & \multirow{4}{*}{ Total } & 1.Illegible & $10(6,1)$ & 76,40 & 18,36 & $48(29,6)$ & 78,69 & 18,47 & $58(17,8)$ & 78,29 & 18,31 \\
\hline & & 2.Medium-level Legible & $67(41,1)$ & 78,47 & 19,34 & $86(53,2)$ & 78,61 & 19,26 & $153(47,2)$ & 78,55 & 19,23 \\
\hline & & 3.Legible & $86(52,8)$ & 73,88 & 18,00 & $28(17,3)$ & 78,32 & 18,34 & $114(35,1)$ & 74,97 & 18,11 \\
\hline & & Total & $163(100)$ & 75,92 & 18,61 & $162(100)$ & 78,58 & 18,76 & $325(100)$ & 77,25 & 18,70 \\
\hline \multirow{12}{*}{$\begin{array}{c}\text { Manuscript } \\
\text { Writing } \\
\text { Speed }\end{array}$} & \multirow{4}{*}{ 4th grade } & 1.Illegible & $5(7,0)$ & 62,30 & 23,04 & $20(26,3)$ & 39,62 & 28,01 & $25(17,0)$ & 44,16 & 28,20 \\
\hline & & 2.Medium-level Legible & $29(40,8)$ & 65,50 & 20,65 & $42(55,3)$ & 51,63 & 21,52 & $71(48,3)$ & 57,30 & 22,11 \\
\hline & & 3.Legible & $37(52,2)$ & 71,31 & 17,66 & $14(19,4)$ & 60,36 & 21,27 & $51(35,7)$ & 68,30 & 19,14 \\
\hline & & Total & $71(100)$ & 68,30 & 19,28 & $76(100)$ & 50,08 & 24,09 & $147(100)$ & 58,88 & 23,66 \\
\hline & \multirow{4}{*}{5 th grade } & 1.Illegible & $5(5,4)$ & 55,30 & 31,13 & $28(32,6)$ & 49,18 & 21,67 & $33(18,5)$ & 50,11 & 22,86 \\
\hline & & 2.Medium-level Legible & $38(41,3)$ & 76,21 & 17,87 & $44(51,2)$ & 65,17 & 20,08 & $82(46,1)$ & 70,29 & 19,76 \\
\hline & & 3.Legible & $49(54,3)$ & 77,14 & 14,54 & $14(16,2)$ & 78,93 & 15,52 & $63(36,4)$ & 77,54 & 14,66 \\
\hline & & Total & $92(100)$ & 75,57 & 17,55 & $86(100)$ & 62,20 & 22,28 & $178(100)$ & 69,11 & 21,02 \\
\hline & \multirow{4}{*}{ Total } & 1.Illegible & $10(6,1)$ & 58,80 & 26,08 & $48(29,6)$ & 45,19 & 24,70 & $58(17,8)$ & 47,54 & 25,24 \\
\hline & & 2.Medium-level Legible & $67(41,1)$ & 71,57 & 19,71 & $86(53,2)$ & 58,56 & 21,77 & $153(47,2)$ & 64,26 & 21,81 \\
\hline & & 3.Legible & $86(52,8)$ & 74,63 & 16,12 & $28(17,3)$ & 69,64 & 20,57 & $114(35,1)$ & 73,41 & 17,36 \\
\hline & & Total & $163(100)$ & 72,40 & 18,62 & $162(100)$ & 56,52 & 23,86 & $325(100)$ & 64,48 & 22,80 \\
\hline
\end{tabular}

Table 5. Legibility and Speed Relationship

\begin{tabular}{|c|c|c|}
\hline & $\begin{array}{c}\text { Manuscript Writing } \\
\text { Legibility }\end{array}$ & $\begin{array}{c}\text { Manuscript } \\
\text { Writing Speed }\end{array}$ \\
\hline $\begin{array}{c}\text { Cursive Italic Writing } \\
\text { Legibility }\end{array}$ &, $828 * *$ &, $248 * *$ \\
\hline $\begin{array}{c}\text { Cursive Italic Writing } \\
\text { Speed }\end{array}$ & & ,366* \\
\hline
\end{tabular}

\subsection{Legibility and Writing Disposition Scores}

Table 6. Legibility and Writing Disposition Scores

\begin{tabular}{|c|c|c|c|c|c|c|}
\hline $\begin{array}{l}\text { Cursive } \\
\text { Legibility }\end{array}$ & $\mathrm{N}$ & M & $\mathrm{S}$ & $\mathrm{F}$ & $\mathrm{P}$ & \\
\hline 1 & 43 & 75,23 & 14,54 & \multirow{3}{*}{9,303} & \multirow{3}{*}{, 000} & \multirow{3}{*}{$\begin{array}{l}1-2 \\
1-3\end{array}$} \\
\hline 2 & 169 & 82,18 & 13,26 & & & \\
\hline 3 & 113 & 85,24 & 11,81 & & & \\
\hline $\begin{array}{c}\text { Manuscript } \\
\text { Legibility }\end{array}$ & $\mathrm{N}$ & M & $\mathrm{S}$ & $\mathrm{F}$ & $\mathrm{P}$ & \\
\hline 1 & 58 & 75,96 & 15,68 & \multirow{3}{*}{12,320} & \multirow{3}{*}{,000 } & \multirow{3}{*}{$\begin{array}{l}1-2 \\
1-3 \\
2-3\end{array}$} \\
\hline 2 & 153 & 81,87 & 12,89 & & & \\
\hline 3 & 114 & 86,17 & 11,08 & & & \\
\hline
\end{tabular}

1: Illegible 2: Medium-Level Legible 3: Legible
It was determined in cursive italic writing that as legibility increased, writing disposition points also increased. There was a significant difference between students with illegible writing and medium-level legible and legible writing $(\mathrm{F}(2-322)=9,303 \mathrm{p}<, 05)$.

In manuscript writing, as the legibility increased, writing disposition points also increased. A significant difference was found between the students in terms of writing disposition in all legibility dimensions $(\mathrm{F}(2-322)=12,320 \mathrm{p}<, 05)$.

\subsection{Preferred Writing Style and Writing Speed}

Table 7. Preferred Writing Style and Writing Speed

\begin{tabular}{|c|c|c|c|c|}
\hline $\begin{array}{c}\text { Which Writing } \\
\text { Do You Prefer? }\end{array}$ & $\mathrm{N}$ & $\%$ & $\begin{array}{c}\text { Cursive } \\
\text { Italic } \\
\text { Writing } \\
\text { Speed* }\end{array}$ & $\begin{array}{c}\text { Manuscript } \\
\text { Writing } \\
\text { Speed* }\end{array}$ \\
\hline $\begin{array}{c}\text { Cursive italic } \\
\text { writing }\end{array}$ & 198 & 60,9 & 76,50 & 59,89 \\
\hline Manuscript & 70 & 21,5 & 79,31 & 74,10 \\
\hline I like both & 32 & 9,8 & 80,67 & 71,25 \\
\hline I dislike both & 25 & 7,7 & 73,02 & 65,26 \\
\hline \multicolumn{7}{|c|}{ Total } & 325 & 100,0 & 77,25 & 64,48 \\
\hline
\end{tabular}


The students answered the question "Which writing do you prefer?" mostly $(60,9 \%)$ as cursive italic writing. In addition, there were considerable number of answers of liking writing with manuscripts $(21,5 \%)$ and writing with both $(9,8 \%)$ by the students who never used manuscripts. It was determined that the fourth and fifth grade students wrote 77,25 letters per minute with cursive italic writing and 64,48 letters with manuscripts. In both writing styles, the slowest writing speed belonged to the students who stated that they did not like writing. The students stating that they like writing with manuscripts were those writing most rapidly with manuscripts. The ones with the least letter writing per minute with manuscripts were the students stating that they liked cursive italic writing.

\section{Conclusions and Discussions}

Writing dispositions of the fifth grade students were higher than the fourth grade students, and writing dispositions of the girl students were higher than the boy students. Writing dispositions of the boy students showed increase with grade. Pajares and Valiante [34] stated that there was no difference in writing performances of girls and boys, however that girls regarded writing as more beneficial and they also had stronger personal competences. According to Clark and Dugdale [11], boys are far beyond girls in writing skill, and they present a negative attitude towards writing compared to girls. Tüfekçioğlu [37] determined in parallel with the research results in the study conducted with 6th grade students that writing dispositions of the girl students were significantly higher than the boy students. Zorbaz [43] detected that girls enjoyed writing more, and the boys had higher writing anxiety than the girls. Işeri [28], Baş and Şahin [7], Tabak and Topuzkanamış [36], and Uçgun [39] detected in their researchers that writing dispositions of girls were in a more positive level compared to boys.

There is a positive, high-level and significant relationship between cursive italic writing and manuscript writing legibility. In both writing styles, the girl students wrote more legibly than the boy students. Graham and oth [21] found similarly in their studies that writings of the girls were more legible than those of the boys. Cursive italic writings of the fourth grade students were more legible than those of the fifth grade students. There is no significant difference in manuscript writing with respect to grades. Memiş and Gülsoy [33] indicated that legibility of the writings of the students reduced as grade increased.

There is a medium-level, positive and significant relationship between cursive italic writing speed and manuscript writing speed of the students. As a result of the study conducted by Graham and oth. [19], it was concluded that there was no significant difference between manuscript writing and cursive italic writing with respect to speed and legibility.
With the dictation method, the girl students in the fourth grade wrote cursive italic writing with 70,16 letters per minute, and the boy students wrote 74,71 letters. Average speed of the girl students in the fifth grade was 80,36 , that of the boy students was 82,31 . It is seen that the results are over writing speed averages of Graham and oth. [22]. Cursive italic writing of the fifth grade students was significantly more rapidly than the fourth grade. The boy students wrote cursive italic writing more rapidly than the girl students. With the dictation method, the girl students in the fourth grade wrote manuscript writing with 68,30 letters per minute, and the boy students wrote 50,08 letters. Average speed of the girl students in the fifth grade was 75,57 , that of the boy students was 62,20 . While cursive italic writing and manuscript writing speed averages of the girl students were close to each other in both grades, it was determined that the boy students wrote cursive writing differently faster compared to manuscript writing in both grades.

No negative relationship was seen between cursive italic writing and speed of the students. As writing speed of the students increased, legibility of their writings decreased. This situation was similar in both class grades. An opposite situation was seen for manuscript writing speed. Speed and legibility showed increase together. Similar to the general results, as cursive italic writing speed of the girl students increased, cursive italic writing legibility decreased. The situation was different with the boy students. Although total points partially showed similarity with these results, the boy students in the fifth grade were concluded to write more rapidly and legibly. The group from the boy students who wrote manuscript writing most rapidly was the one with students with legible cursive italic writing. A complicated table was presented for the girl students.

There was no differentiation in cursive italic writing speed of the students with respect to manuscript writing legibility statuses. Also, no difference was seen for age and gender variables. Manuscript writing legibility and speed of the students showed increase together. The situation was the same for the girls and the boys in all class grades.

It was determined that the students wrote cursive italic writing more rapidly than manuscript writing in all legibility levels. In both writing styles, as legibility increased, writing disposition points increased significantly.

The students mostly stated that they liked cursive italic writing. In addition, there are considerable number of answers of liking writing with manuscripts and writing with both by the students who never used manuscripts. The lowest writing speed in both writing styles belonged to the students stating that they did not like writing. The students stating that they liked writing with manuscripts were the ones who wrote with manuscripts most rapidly. Those with the least letter number per minute with 
manuscripts were the students stating that they liked cursive italic writing.

\section{REFERENCES}

[1] Akyol, H. Türkçe İlk Okuma Yazma Öğretimi. Ankara: Pegem A Yayıncilık, 2005.

[2] Arslan,D; Ilgın,H. Öğretmen ve Öğrencilerin Bitişik Eğik Yazı ile İlgili Görüşleri, İnönü Üniversitesi Eğitim Fakültesi Dergisi,11(2), 69-92,2010.

[3] Arslan, N., Durukan,E. Ortaokul Öğrencilerinin Öğrenme Stilleri ve Yazma Eğilimleri Arasındaki İlişki, Uluslararası Türkçe Edebiyat Kültür Eğitim Dergisi, 4(3), 1251-1267,2015.

[4] Avc1, A.S., İşeri,K. Yaratıcı Yazma Etkinliklerinin Sekizinci Sınıf Ögrencilerinin Yazma Eğilimleri ve Yazma Kaygilarına Etkisi, International Journal of Language Academy, 2(4), 152-169, 2014.

[5] Baş, G. Correlation between Elementary Students' Reading Attitudes and Their Writing Dispositions, IJGE: International Journal of Global Education, 1(2), 1-6, 2012.

[6] Baş,G.,Şahin, C. İlköğretim 6. 7. ve 8. Sınıf Öğrencilerinin Okuma Tutumları Ve Yazma Eğilimleri İle Türkçe Dersindeki Akademik Başarıları Arasındaki İlișki, Turkish Studies, 7(3), 555-572, 2012.

[7] Baş,G.,Şahin, C. İlköğretim Öğrencilerinin Yazma Eğilimlerinin Farklı Değișkenler Açısından İncelenmesi, Sakarya University Journal of Education, 3(1),32-42, 2013.

[8] Başaran, M. İlk Okuma Yazma Öğretimi Sürecinde Öğrencilerin Yaptıkları Yazım Yanlışları. Ulusal Sınıf Öğretmenliği Kongresi Tam Metin Kitapçı̆̆ı, Gazi Üniversitesi, Ankara: Kök Yayıncılık. 109-114,2006.

[9] Baștuğ,M. İlkokul Dördüncü Sınıf Öğrencilerinin Yazma Eğilimi, Tutumu ve Yazma Tutukluğunun Yazma Başarısı Üzerine Etkisi, Eğitim ve Bilim, 40 (180), 73-88, 2015.

[10] Berninger, Virginia W.; Rutberg, Judith E.; Abbott, Robert D.; Garcia, Noelia; Anderson-Youngstrom, Marci; Brooks, Allison; Fulton, Cynthia. Tier 1 and Tier 2 Early Intervention for Handwriting and Composing, Journal of School Psychology, 44(1), 3-30, 2006.

[11] Clark,C., Dugdale,G. Young People's Writing: Attitudes, Behaviour and the Role Of Technology, National Literacy Trust, 2009. http://files.eric.ed.gov/fulltext/ED510271.pdf 05.08.2017

[12] Coşkun, E., Coşkun, H.. İlköğretim Öğrencileri ile Sınıf ve Türkçe Öğretmenlerinin Bitişik Eğik Yazı Başarı Düzeylerinin Değerlendirilmesi, GEFAD / GUJGEF, 32(3): 761-776, 2012.

[13] Çeçen, M. A. ve Deniz, E. Ortaöğretim Öğrencilerinin Yazma Eğilimi Algıları (Diyarbakır İli Örneği). Ana Dili Eğitimi Dergisi, 3(2), 35-48, 2015.

[14] Demir, K. G. Ilköğretim Birinci ve İkinci Kademe Öğrencilerin Yazım Hataları ve Öğretmen Görüşleri.
Yayımlanmamıș Yüksek Lisans Tezi, Gazi Üniversitesi, Ankara, 2003.

[15] Duran,E. Bitişik Eğik Yazı Harflerinin Yazım Şekillerine İlişkin Öğretmen Görüşleri, Ondokuz Mayıs Üniversitesi Eğitim Fakültesi Dergisi, 30(2), 55-69, 2011

[16] Engel-Yeger, B., Nagauker-Yanuv, L., Rosenblum, S Handwriting performance, self-reports, and perceived self-efficacy among children with dysgraphia. American Journal of Occupational Therapy, 63, 182-192, 2009.

[17] Erdoğan,T. İlköğretim Birinci Sınıf Öğrencilerinin Bitişik Eğik Yazı Yazma Gelişimlerinin İncelenmesi, Eğitim ve Bilim, 37(165), 93-103, 2012.

[18] Feder, K. P., \& Majnemer, A. (2007). Handwriting development, competency, and intervention. Developmental Medicine and Child Neurology, 49, 312 317. 2007.

[19] Graham, S., \& Miller, L. Handwriting research and practice: A unified approach. Focus on Exceptional Children, 13, $1-16,1980$.

[20] Graham, S. A review of handwriting scales and factors that contribute to variability in handwriting scores. Journal of School Psychology, 24, 63-72, 1986.

[21] Graham, S., Berninger, V.W.,Weintraub N., Schafer,W. Development of Handwriting Speed and Legibility in Grades 1-9, The Journal of Educational Research, 92(1), 42-52, 1998.

[22] Graham, S., Berninger, V.W., Weintraub, N. The Relationship between Handwriting Style and Speed and Legibility. The Journal of Educational Research, 91(5), 290-297, 1998.

[23] Graham, S., Harris, K.R., Fink, B. Is Handwriting Causally Related to Learning to Write? Treatment of Handwriting Problems in Beginning Writers. Journal of Educational Psychology 92, 620-633, 2000.

[24] Güneş, F. Ses Temelli Cümle Yöntemi ve Zihinsel Yapılandırma, Nobel Yayın Dağıtım, Ankara, 2007.

[25] Hawthorne, J. The Effects Of The Delivery Style Of Teacher Feedback On The Writing Self-Efficacy And Dispositions Of Young Students, (Yayınlanmamış Doktora Tezi), ProQuest Dissertations ve Theses Tam Metin veri tabanından 04.08.2017 tarihinde erişildi. (Umi Number: 3458703), 2010.

[26] Hong,S.Y.; Jung, N.H.;Kim, K.M.The correlation between proprioception and handwriting legibility in children, $\mathrm{J}$. Phys. Ther. Sci. 28: 2849-2851, 2016.

[27] Işeri, K., Ünal, E.Yazma Eğilimi Ölçeği'nin Türkçeye Uyarlanması, Eğitim ve Bilim, 35(155), 104-117, 2010.

[28] İsseri, K. Evaluation of Writing Dispositions of Elementary School Sixth Grade Students. The New Educational Review, 22(3-4), 295-305, 2010.

[29] Kadığlu Ateş,H. İlkokul Birinci Sınıf Öğrencilerinin Bitişik Eğik Yazılarının Yazma Özelliklerinin İlișkileri Açısından İncelenmesi, Akademik Sosyal Araştırmalar Dergisi, 3(17), 200-219, 2015.

[30] Lee, T.I.; Howe, T.H.; Chen, H.L.; Wang, T. N. Predicting 
Handwriting Legibility in Taiwanese Elementary School Children, The American Journal of Occupational Therapy, 70(6), 1-9, 2016

[31] McClenny, C. S. A disposition to write: Relationships with writing performance. (Yayınlanmamış doktora tezi) ProQuest Dissertations ve Theses Tam Metin veri tabanından 04.08.2017 tarihinde erişildi. (UMI No: 3458714),https://search.proquest.com/pqdtglobal/docview/ 871897604/fulltextPDF/C6320C2B5EE84671PQ/1?accou ntid=17396, 2010 .

[32] Medwell, J.,Wray, D. Handwriting: what we know and need to know?, Literacy, 41 (1), 2007.

[33] Memiş, A., Gülsoy,Y. İlkokul Öğrencilerinin Bitişik Eğik El Yazısı Okunaklılık Durumları, 15.Uluslararas1 Sinıf Öğretmenliği Eğitimi Sempozyumu, 11-14 Mayıs 2016.

[34] Pajares, F., Valiante,G. Grade Level and Gender Differences in the Writing Self-Beliefs of Middle School Students, Contemp Educ Psychol.,24(4), 390-405, 1999.

[35] Piazza, C. L. \& Siebert, C. F. Development and validation of a writing disposition scale for elementary and middle school students. The Journal of Educational Research, 101(5), 275-285, 2008.

[36] Tabak, G., Topuzkanamış,E. An Analysis of Writing Dispositions of 6th Grade Students in terms of Different Variables, Mevlana International Journal of Education (MIJE), 4(2),1-11, 2014.
[37] Tüfekçioğlu, B. Yazma Becerisinin Bazı Değişkenler Açısından İncelenmesi. Dil Dergisi, 149, 30-45, 2010.

[38] Türkçe Dersi $(1,2,3,4,5,6,7$ ve 8 . Sinıflar) Öğretim Program1. Milli Eğitim Bakanlı̆̆ http://mufredat.meb.gov.tr/Dosyalar/201812312239736-Tü rkçe\%20Öğretim\%20Programı\%202018.pdf, 2018.

[39] Uçgun, D. Altıncı Sınıf Öğrencilerinin Yazma Eğilimlerinin İncelenmesi. Egitim ve Bilim, 39 (175), 227-238, 2014.

[40] Ünal, E. An Analysis of the Writing Dispositions of Fourth and Fifth Grade Elementary School Pupils. Education, 131(2), 319-330, 2010.

[41] Yıldız, M., Yıldırım, K., \&. Ateş, S. Sınıf Öğretmenlerinin Sinıf Tahtasına Yazdıkları Yazıların Okunaklılık Bakımından Öğrencilere Model Olmadaki Uygunluğu. Uluslararası İnsan Bilimleri Dergisi, 6(2), 75-88. Erişim: http://www.insanbilimleri.com, 2009.

[42] Yıldız, M., Ateş, S. İlk Okuma Yazmayı Farklı Yöntemlerle Öğrenen İlköğretim 3. Sınıf Öğrencilerinin Yazılarının Okunaklı1ık ve Yazım Hataları Bakımından Karşılaştırılması, TSA, 14(1), 11-30, 2010.

[43] Zorbaz, K.Z. İlköğretim okulu öğrencilerinin yazma kayg ve tutukluğunun yazılı anlatım becerileriyle ilişkisi, Gazi Üniversitesi Eğitim Bilimleri Enstitüsü Yayınlanmamış Doktora Tezi, 2010. 